Andrei A. Orlov

Milwaukee, Wisconsin, USA

\title{
TITLES OF ENOCH-METATRON IN 2 (SLAVONIC) ENOCH ${ }^{1}$
}

\begin{abstract}
Whoever is dealing with the Account of Creation and the Account of the Chariot must inevitably fail. It is therefore written, «Let this heap of ruins be under your hand» (Isa. 3.6). This refers to things that a person can not understand, unless he fails in them.
\end{abstract}

(The Book of Bahir, 150)

In his introduction to the English translation of 2 Enoch F. I. Andersen states that «all attempts ${ }^{2}$ to locate the intellectual background of the book

${ }^{1}$ Part of this paper was read at the Annual Meeting of SBL/AAR, New Orleans, 23-26 November 1996.

${ }^{2}$ On different approaches to 2 Enoch, cf. И. Д. Амусин, Тексты Кумрана (Mocква, 1971) (Памятники письменности востока, 33/I); F. I. ANDERSEN, 2 (Slavonic Apocalypse of) Enoch // OTP. Vol. 1. 91-221; C. BöTTRich, Adam als Mikrokosmos: Eine Untersuchung zum slavischen Henochbuch (Frankfurt am Main, 1995) (Judentum und Umwelt, 59); IDEM, Das slavische Henochbuch (Gütersloh, 1995) (JSHRZ, 5); IDEM, Weltweisheit, Menschheitsethik, Urkult; Studien zum slavische Henochbuch (Tübingen, 1992) (WUNT, 2/50); R. H. Charles, The Date and Place of Writings of the Slavonic Enoch // JTS 22 (1921) 161-163 (163); J. H. CharlesworTh, In the Crucible: The Pseudepigrapha as Biblical Interpretation // Pseudepigrapha and Early Biblical Interpretation / Ed. J. H. Charlesworth, C. A. Evans (Sheffield, 1993) (JSPSS, 14) 20-43; J. H. Charlesworth, The Old Testament Pseudepigrapha and the New Testament: Prolegomena for the Study of Christian Origins (Cambridge, 1985) (SNTSMS, 54); IDEM, The Pseudepigrapha and Modern Research with a Supplement (Chico, CA, 1981) (SBLSCS, 7); J. Collins, The Genre Apocalypse in Hellenistic Judaism // Apocalypticism in the Mediterranean World and the Near East / Ed. D. HELLHOLM (Tübingen, 1983); L. GRY, Quelques noms d'anges ou d'êtres mystérieux en II Hénoch // RB 49 (1940) 195-203; J. DaniéLou, The Theology of Jewish Christianity (Chicago, 1964); U. FISCHER, Eschatologie und Jenseitserwartung im hellenistischen Diasporajudentum (Berlin, 1978) (BZNW, 44); J. Fossum, Colossians 1.15-18a in the Light of Jewish Mysticism and Gnosticism // NTS 35 (1989) 183-201; K. LAKE, The Date of the Slavonic Enoch // HTR 16 (1923) 397-398; Н. А. МЕщЕРский, Следы памятников Кумрана в старославянской и древнерусской литературе (К изучению славянских версий книги Еноха) // Труды Отдела Древнерусской Литературы 19 (1963) 130-147; он жЕ, К истории текста славянской книги Еноха (Следы памятников Кумрана в византийской и старославянской литературе) // $B B 24$ 
have failed». ${ }^{3}$ Among these endeavors were several efforts to establish the connection between 2 Enoch and Ma ${ }^{c}$ aseh Merkabah. ${ }^{4}$ One of the essential

(1964) 91-108; Он жЕ, К вопросу об источниках славянской Книги Еноха // Kpamкие Сообщения Института Народов Азии 86 (1965) 72-78; J. T. Miliк, The Books of Enoch: Aramaic Fragments of Qumran Cave 4 (Oxford, 1976); G. W. E. NicKelsBURG, The Books of Enoch in Recent Research // RSR 7 (1981) 210-217: H. ODEBERG, 3 Enoch or the Hebrew Book of Enoch (New York, 1973); M. PhILONENKo, La cosmogonie du «Livre des secrets d'Hénoch» // Religions en Égypte: Hellénistique et romaine (Paris, 1969); S. PINES, Eschatology and the Concept of Time in the Slavonic Book of Enoch // Types of Redemption / Ed. R. J. Zwi Werblowsky, J. Jouco BLEEKER (Leiden, 1970) (SHR, 18) 72-87; J. ReEves, Jewish Pseudepigrapha in Manichaean Literature: The Influence of the Enochic Library // Tracing the Threads: Studies in the Vitality of Jewish Pseudepigrapha / Ed. J. C. ReEves (Atlanta, CA, 1994) (EJL, 6) 173-203: A. Rubinstein, Observations on the Slavonic Book of Enoch // JJS 15 (1962) 1-21; G. Scholem, Major Trends in Jewish Mysticism (New York, 1954); IDEM, On the Mystical Shape of the Godhead (New York, 1991); IDEM, Origins of the Kabbalah (Princeton, NJ, 1987); M. Scopello, The Apocalypse of Zostrianos (Nag Hammadi VIII.1) and the Book of the Secrets of Enoch // VC 34 (1980) 367-385; M. E. Stone, Jewish Writings of the Second Temple Period (Assen-Philadelphia, 1984) (CRINT, 2.2) 2. 406-408; A. VaILlant, Le livre des secrets d'Hénoch: Texte slave et traduction française (Paris, 1952; repr. Paris, 1976); J. VANDERKAm, Enoch, A Man for All Generations (Columbia, 1995).

${ }^{3}$ Andersen, 2 Enoch... 95.

${ }^{4}$ On the Merkabah tradition, see the following sources: P. AleXAnder, The Historical Settings of the Hebrew Book of Enoch // JJS 28 (1977) 156-180; D. BLuMENTHAL, Understanding Jewish Mysticism, a Source Reader: The Merkabah Tradition and the Zoharic Tradition. 2 vols (New York, 1978); I. Chernus, Mysticism in Rabbinic Judaism (Berlin, 1982) (SJ, 11); M. CoHEN, The Shicur Qomah: Liturgy and Theurgy in Pre-Kabbalistic Jewish Mysticism (Lanham, 1983); J. GREENFIELD, Prolegomenon // Odeberg, 3 Enoch... xi-xlvii; I. Gruenwald, Apocalyptic and Merkavah Mysticism (Leiden, 1980) (AGJU, 14); I. Gruenwald, M. Smith, The Hekhaloth Literature in English (Chico, CA, 1983); D. HALPERIN, The Faces of the Chariot: Early Jewish Responses to Ezekiel's Vision (Tübingen, 1988) (TSAJ, 16); IDEM, The Merkavah in Rabbinic Literature (New Haven, 1980); M. IDEL, Enoch is Metatron // Immanuel 24/25 (1990) 220-240; L. JACOBS, Jewish Mystical Testimonies (New York, 1977); N. Janowitz, The Poetics of Ascent: Theories of Language in a Rabbinic Ascent Text (Albany, 1989); M. Morgan, Sepher Ha-Razim: The Book of Mysteries (Chico, CA, 1983) (TTPS, 11); C. Morray-Jones, Hekhaloth Literature and Talmudic Tradition: Alexander's Three Test Cases // JJS 22 (1991) 1-39; C. Newsom, Songs of the Sabbath Sacrifice: A Critical Edition (Atlanta, GA, 1985) (HSS, 27); P. SCHÄFER with M. SCHLÜTER and H. G. von Mutius, Synopse zur Hekhalot-Literatur (Tübingen, 1981) (TSAJ, 2); P. SCHÄFER, The Hidden and Manifest God (Albany, 1992); P. SCHÄFER et al., Übersetzung der Hekhalot-Literatur. 4 vols (Tübingen, 1987-1995) (TSAJ, 17, 22, 29, 46); G. Scholem, Jewish Gnosticism, Merkabah Mysticism and Talmudic Tradition (New York, 1965); IDEM, Major Trends in Jewish Mysticism (New York, 1954); N. SÉD, Les traditions secrètes et les disciples de Rabban Yohannan ben Zak- 
contributors to this approach, Hugo Odeberg 5 points out that the similarities in descriptions of celestial titles for Enoch in 2 and 3 Enoch may be the important evidence of a possible connection between 2 Enoch and texts of the Merkabah tradition.

The purpose of this chapter is to call attention to some details of these descriptions which might shed new light on the relationship between early Enochic ${ }^{6}$ and Merkabah traditions.

\section{The Prince of the Presence}

The substantial part of 2 Enoch's narrative is dedicated to Enoch's ascent into the celestial realm and to his heavenly metamorphosis near the Throne of Glory. In these lengthy and elaborated descriptions of Enoch's transformation into a celestial being, on a level with the archangels, one may find the origin of another image of Enoch which was developed later in Merkabah mysticism, that is, the image of the angel Metatron, the Prince of the Presence.

Odeberg may well be the first scholar to have discovered the characteristics of «the Prince of the Presence» in the long recension of 2 Enoch. He successfully demonstrated in his synopsis of the parallel passages from 2 and 3 Enoch, that the phrase «stand before my face forever» ${ }^{7}$ does not serve merely

kai // RHR 184 (1973) 49-66; M. Swartz, Mystical Prayer in Ancient Judaism: An Analysis of Macaseh Merkavah (Tübingen, 1992) (TSAJ, 28).

${ }^{5}$ Odeberg, 3 Enoch...

${ }^{6}$ On the figure of Enoch and Enochic traditions see: M. BLACK, The Book of Enoch or 1 Enoch: A New English Edition with Commentary and Textual Notes (Leiden, 1985) (SVTP, 7); Charlesworth, The Old Testament Pseudepigrapha and the New Testament...; IDEM, The Pseudepigrapha...; J. Collins, The Apocalyptic Imagination: An Introduction to the Jewish Matrix of Christianity (New York, 1984) 33-67; P. Grelot, La légende d'Hénoch dans les apocryphes et dans la Bible: son origine et signification // RSR 46 (1958) 5-26, 181-210; H. L. JANSEN, Die Henochgestalt: Eine vergleichende religionsgeschichtliche Untersuchung (Oslo, 1939) (Norske Videnskaps-Akademi i Oslo II. Hist.-Filos. Klasse, 1); H. Kvanvig, Roots of Apocalyptic: The Mesopotamian Background of the Enoch Figure and the Son of Man (Neukirchen-Vluyn, 1988) (WMANT, 61); MiLIK, The Books of Enoch...; OdeBERG, 3 Enoch...; M. STONE, Selected Studies in Pseudepigrapha and Apocrypha with Special Reference to Armenian Tradition (Leiden, 1991); M. STone, The Book of Enoch and Judaism in the Third Century BCE // CBQ 40 (1978) 479-492; J. VANDERKAM, Enoch Traditions in Jubilees and Other Second-Century Sources // SBLSP (1978) 1. 229-251; IDEM, Enoch and the Growth of an Apocalyptic Tradition (Washington, 1984) (CBQMS, 16); IDEM, Enoch, A Man for All Generations... On Merkabah features of Enochic traditions, see P. Alexander, 3 (Hebrew Apocalypse of) Enoch // OTP. Vol. 1. 247-248; Greenfield, Prolegomenon... xvi-xxi; Gruenwald, Apocalyptic and Merkavah Mysticism... 32-51.

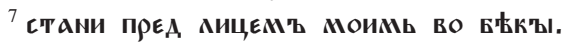


as a normal Hebraism «to be in the presence», but establishes the angelic

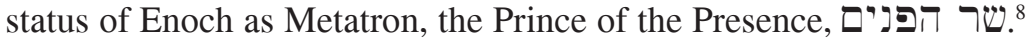

The title itself is developed mainly in chs. 21-22, which are dedicated to the description of the Throne of Glory. In these chapters, one finds many promises that Enoch will «stand in front of the face of the Lord forever». ${ }^{9}$

In terms of the theological background of the problem, the title seems connected with the image of Metatron in the Merkabah tradition, ${ }^{10}$ which was «crystallized in the classical Hekhalot literature». ${ }^{11}$ According to the legend of the Hekhalot tradition, Enoch «was raised to the rank of first of the angels and שר הפנים (literally, 'prince of the divine face', or 'divine presence')». ${ }^{12} 3$ Enoch, as well as other texts of the tradition, have a well-developed theology connected with this title.

\section{The Knower of Secrets}

The Merkabah tradition emphasizes the role of Metatron as the «Knower

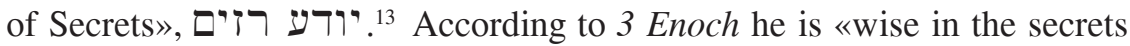
and Master of the mysteries». ${ }^{14} \mathrm{He}$ is the one who received these secrets from the angels and from the Lord (the Holy One). He serves also as «the Revealer of Secrets», the one who is responsible for the transmission of the highest secrets to the Princes under him, as well as to humankind. In ch. 38 of 3 Enoch, Metatron told R. Ishmael that he was the person who revealed secrets to Moses, in spite of the protests of heavenly hosts:

...when I revealed this secret to Moses, then all the host in every heaven on high raged against me and said to me: Why do you reveal this secret to a son of man...the secret by which were created heaven and earth... and the Torah and Wisdom and Knowledge and Thought and the Gnosis of things above and the fear of heaven. Why do you reveal this to flesh and blood? ${ }^{15}$

According to this theological material, Enoch (Metatron) is responsible for transmitting the secrets of the Written Torah as well as the Oral Tradition. «And Metatron brought them out from his house of treasuries and committed

${ }^{8}$ Odeberg, 3 Enoch... 1.55.

${ }^{9}$ Cf. $21: 3 ; 21: 5 ; 22: 6 ; 22: 7$.

${ }^{10}$ Scholem, Major Trends in Jewish Mysticism... 67.

${ }^{11}$ About different stages in the Hekhalot tradition, see Gruenwald, Apocalyptic and Merkavah Mysticism... 67; 98-123.

${ }^{12}$ Scholem, Major Trends in Jewish Mysticism... 67.

${ }^{13}$ The origin of the role in Enochic traditions can be traced to 1 Enoch 72:1; 74:2 and 80:1. See also 41:1, «And after this I saw all secrets of heaven». M. KNIBB, The Ethiopic Book of Enoch. 2 vols (Oxford, 1978) Vol. 2. 128.

${ }^{14}$ Odeberg, 3 Enoch... 2.30.

${ }^{15}$ Ibid. 2.177-178. 
them to Moses, and Moses to Joshua, and Joshua to the elders, and the elders to the prophets and the prophets to the men of the Great Synagogue...». ${ }^{16}$

In later Merkabah materials, Enoch-Metatron is the guide and the revealer of secrets to all who are initiated into the account of the Chariot. ${ }^{17}$ Hekhalot literature (3 Enoch, the Shicur Qomah materials) describes these functions of Metatron. He guides and reveals secrets to R. Ishmael and to R. Akiba. Sometimes the Merkabah narrative extends his role to the titles of the Prince of Wisdom and the Prince of Understanding. ${ }^{18}$

It is apparent that in 2 Enoch one may see some kind of preparation of Enoch for his role as Metatron, «the Knower of Secrets». The preparation entails several stages. First, the archangel Vereveil inducts Enoch into these secrets. He instructs Enoch in «all the deeds of the Lord, the earth and the sea, and all the elements and the courses... and the Hebrew language, every kind of language of the new song of the armed troops and everything that it is appropriate to learn» (23:1-2). Second, the Lord himself continues to instruct him in the secrets, which he had not even explained to the angels (24:3). Finally, the Lord promised Enoch the role of «Knower of Secrets». The important detail here is that the promise of the role is closely connected with other titles of Metatron such as the Prince of Presence, the Heavenly Scribe, and the Witness of the Judgment. In the text the Lord promised:

... and you will be in front of my face from now and forever. ${ }^{19}$ And you will be seeing my secrets ${ }^{20}$ and you will be scribe for my servants ${ }^{21}$ since you will be writing down everything that has happened on earth and that exists on earth and in the heavens, and you will be for me a witness of the judgment ${ }^{22}$ of the great age (36:3).

This substantial passage graphically depicts the interrelation of the future roles of Enoch-Metatron in the narrative of 2 Enoch. In spite of the fact that the text does not elaborate the real embodiments of these roles and titles, but only promises and initiations in these roles, it leaves the impression that 2 Enoch is part of the larger tradition and that its author has prior knowledge of the future development of these titles and the deeds behind them.

\footnotetext{
${ }^{16}$ Odeberg, 3 Enoch... 2.178.

${ }^{17}$ Metatron himself was the Merkabah mystic par excellence and a good example for Yorde Merkabah. As Alexander notes, it is not hard to see why he attracted mystics. «He was a human being who had been elevated over all the angels, and was living proof that man could overcome angelic opposition and approach God. He was a powerful "friend at court"». AleXANDER, 3 Enoch... 244.

${ }^{18}$ Odeberg, 3 Enoch... 2.30.

19 «The Prince of the Presence».

20 «The Knower of Secrets».

${ }^{21}$ «The Heavenly Scribe».

22 «The Witness of the Divine Judgment».
} 
It is intriguing that the narrative of 2 Enoch does not show the promised powerful deeds of Enoch-Metatron in different offices of the heavenly realm, for example, those of the Knower, the Scribe, the Witness and the Prince of Presence even in early «primitive» Merkabah or apocalyptic form. It looks as if the author of the text deliberately avoids these details. He knows that it is not time for revealing these facts. Enoch must return to the earth, and only after that trip he will fully assume his heavenly offices. In 67:2, which serves as the conclusion to Enoch's story, there is a statement about the theme: «and the Lord received him and made him stand in front of his face for eternity».23

In this regard, the narratives of 2 Enoch and 3 Enoch seem to be written from different temporal perspectives. The setting of Enoch's story in 2 Enoch is the antediluvian period. Melchizedek's narrative of the book distinctively stresses this point. This explains why in 2 Enoch «there is no place for Abraham, Moses, and the rest». ${ }^{24}$

\section{The Heavenly Scribe}

Odeberg notices that Enoch's initiation into the Secrets (and his title the Knower of Secrets) is closely connected with his scribal activities ${ }^{25}$ and with his other title — «the Scribe» ${ }^{26}$ (רופר) or «the Heavenly Scribe». ${ }^{27}$ The steps in the development of this theme in 2 Enoch are apparent. Enoch's scribal functions have several aspects:

1. He was initiated into the scribal activities by the Lord himself. «And the Lord said to Vereveil, "Bring out the books from the storehouses, and

${ }^{23}$ Andersen, 2 Enoch... 195.

${ }^{24}$ Ibid. 196.

${ }^{25}$ In early Enochic traditions these two functions are also unified. The motif of initiation into the secrets as the beginning of scribal activities occupies a substantial role in the Astronomical Book of 1 Enoch, the oldest Enochic material. In 1 Enoch 74:2 Enoch writes the instructions of the angel Uriel regarding the secrects of heavenly bodies and their movements. KNIBB, The Ethiopic Book of Enoch... Vol. 2. 173. Qumran Enochic fragments (4QEnGiants 14; 4QEn 92:1) picture Enoch as «the scribe of distinction» פרפר פרש. Cf. MiLik, The Book of Enoch... 261-262 and 305. In the book of Jubilees Enoch is attested as «the first who learned writings and knowledge and wisdom... And who wrote in the book the signs of the heaven». O. S. W INTERMUTE, Jubilees // OTP. Vol. 2. 62.

${ }^{26}$ The origin of the title in Enochic traditions can be traced to the Book of the Watchers (1 Enoch 12:4, 15:1), where Enoch is named as «a scribe of righteousness». KNIBB, The Ethiopic Book of Enoch... Vol. 2. 92 and 100. According to Black the possible biblical parallel to Enoch's role as the Scribe could be the passage from Ezek. 9, which pictures man clad in white linen with an ink-horn by his side. Black, The Book of Enoch, 143.

${ }^{27}$ Odeberg, 3 Enoch... 1.56. 
give a pen to $\mathrm{Enoch}^{28}$ and read him the books". And Vereveil... gave me the $\operatorname{pen}^{29}$ from his hand» $(22: 11){ }^{30}$

2. He writes down the mysteries which were explained to him by angels. In 23:4 angel Vereveil commands him: «Write everything that I have explained to you». ${ }^{31}$

3. The results of his scribal activity were a certain number of books. «I wrote accurately. And I expounded 300 and 60 books» (23:6). ${ }^{32}$

4. The Lord instructed Enoch to deliver these books in his handwriting to his sons,$^{33}$ and to distribute the books in his handwriting to his children... for they will read them from generation to generation (33:8-10).

5. The Lord appointed the guardian angels for Enoch's writings:

For I will give you an intercessor, Enoch, my archistratig, Michael, on account of your handwritings and the handwritings of your fathers - Adam and Seth. They will not be destroyed until the final age. For I have commanded my angels Arioch and Marioch, whom I have appointed on the earth to guard them and to command the things of time to preserve the handwritings of your fathers so that they might not perish in the impending flood which I will create in your generation (33:10-12.) (4 $^{34}$

The motif of the guardian angels of the books is very specific for the esoterism of Merkabah tradition. ${ }^{35}$ This motif can be found in 3 Enoch as well as in other texts of the tradition.

6. Finally the Lord gave the promise to Enoch about his future role as the Heavenly Scribe when he will return to heaven after the instructions of his sons, «... and you will be the scribe ${ }^{36}$ for my servants, since you will be writing down everything that has happened on earth and that exists on earth and in the heavens, and you will be for me a witness of the judgment of the great age» $(36: 3) .^{37}$

${ }^{28}$ вади же трость Gнохови.

${ }^{29}$ вААСть ми трость.

${ }^{30}$ AndERSEN, 2 Enoch... 141.

${ }^{31}$ Ibid.

${ }^{32}$ Ibid.

${ }^{33}$ In 1 Enoch 81:6 the angel Uriel commands to Enoch: «teach your children, and write (these things) down for them, and testify to all your children». KNIBB, The Ethiopic Book of Enoch... Vol. 2. 187.

${ }^{34}$ Andersen, 2 Enoch... 157.

${ }^{35}$ Alexander notes that «classic rabbinical literature makes it clear that there was an esoteric doctrine in Talmudic Judaism. It was concerned with two subjects - the Account of Creation (Macaseh Berešit) and the Account of the Chariot (Maceh Merkabah). All study and discussion of these topics in public was banned». AleXANDER, 3 Enoch... 229-230.

${ }^{36}$ кмижмик.

${ }^{37}$ It is an important moment for understanding of the presence of Merkabah tradition in the text of 2 Enoch: the functions of Enoch as the Scribe will be connected 
Finally, it is worth examining an interesting detail that is relevant as a characteristic of a hypothetical provenance, but which has remained unnoticed by scholars. In 23:4, when Enoch was already in the highest realms, Vereveil gave him permission to sit down. ${ }^{38}$ "You sit down; write everything...». And Enoch said, «And I sat down ${ }^{39}$ for a second period of 30 days and 30 nights, and I wrote accurately» $(23: 6) .^{40}$ It is important to notice that Vereveil's suggestion that Enoch be seated occurs after Enoch has been «brought in front of the face of the Lord» (22:6), and after he has been invited by the Lord «to stand in front of his face forever» (22.6-7). According to rabbinic tradition, «there is no sitting in heaven». ${ }^{41}$ An allegorical description, which can be found in 3 Enoch, depicts God as the one who places Metatron on a throne at the door of the Seventh Hall. ${ }^{42}$ In his commentary on this section of 3 Enoch, Odeberg states that «assigning a seat or a throne to any angel-prince or to any one beside the Holy One, might endanger the recognition of the absolute sovereignty and unity of the Godhead».$^{43}$ Furthermore, he reasoned that according to rabbinic tradition the privilege of «sitting» was accorded to Metatron by virtue of his character as «scribe», for he was granted permission as a scribe «to sit and write down the merits of Israel». ${ }^{44}$ This fact, that Enoch was seated in the text of 2 Enoch, is one more compelling example that further strengthens the hypothesis regarding the connection of the text of 2 Enoch with the Merkabah tradition.

\section{The Youth}

Previous research has shown that the descriptions of the celestial titles in 2 Enoch occupy some sort of intermediate position between early Enochic traditions and the Metatron tradition. Therefore, some later titles of Metatron, which are absent in 1 Enoch, Jubilees and the Qumran materials are presented in the narrative of 2 Enoch. A good illustration of this situation could be the observation of another celestial title of Enoch-Metatron which

with his role as the Witness of the Divine Judgment: «Metatron sits and judges the heavenly household» or «Metatron, the angel of the Presence, stands at the door of the Palace of God and he sits and judges all the heavenly hosts before his Master. And God pronounces judgment and he executes it». ODEBERG, 3 Enoch... 2.171.

\footnotetext{
${ }^{38}$ сААи.

${ }^{39}$ c中AOX.

${ }^{40}$ ANDERSEN, 2 Enoch... 141.

${ }^{41}$ b. Hag. 15a.

423 En. 10.

${ }^{43}$ Odeberg, 3 Enoch... 2.27.

${ }^{44}$ Ibid.
} 


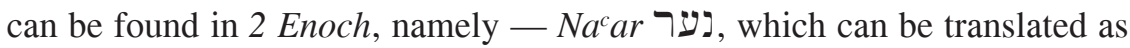
the Youth or the Lad. ${ }^{45}$

According to Jewish mystical lore, this title could be considered as «proof» of the theological assumption that Metatron is the translated Enoch ben Yared. The tradition derives this title from the exegesis of Prov. 22.6 (חנך לנער), which was interpreted as «Enoch was made into the $\mathrm{Na}^{c} \mathrm{ar}$, i.e. Metatron». ${ }^{46}$

The title «Youth» in the Merkabah tradition has several possible theological meanings. According to one of them, the name may be explained by the fact that Metatron grows old, and is then constantly rejuvenated. ${ }^{47}$ Another possible explanation is that he is young in comparison with other angelsprinces who existed from the beginning. ${ }^{48}$ It is notable, that the several important occurrences of the title «Youth» in the text of 2 Enoch come from the mouths of angels. In chapter 9 of the short recension an angelic being, who is accompanying Enoch on his way through the heavenly realm, addresses Enoch as «Youth»: «This place has been prepared, Youth (юnоше), for the righteous.... ${ }^{49}$ Later in chapter 10 we can hear the same address again: «This place, Youth (юооше), has been prepared for those who practice godless uncleanness on the earth...» ${ }^{50}$ These occurrences could be considered by someone simply as reminders for Enoch about his novice status in the heavenly realm. This, however, is not the case with the Merkabah tradition, where $N a^{c} a r$ also designates special relationships between the Holy One and Metatron. In 3 Enoch when R. Ishmael asks Metatron «What is your name?» Metatron answers, «I have seventy names, corresponding to the seventy tongues of the world... but my King calls me «Youth» $\left(\mathrm{Na} \mathrm{c}^{\mathrm{a}} \mathrm{r}\right) » .{ }^{51}$ Interestingly enough, we can see the beginning of this tradition in the text of 2 Enoch. In chapter 24 of the short recension ${ }^{52}$ we read: «And the Lord called me (Enoch) and he placed me to himself closer than Gabriel. And the Lord spoke to me "What-

${ }^{45}$ According to Tishby it is the most popular title of Metatron. «Metatron is known by many names and titles, but his regular designation, found even in the earlier literature, is עער, $n a^{c} a r$ — «boy», or «lad». I. Tishby, The Wisdom of the Zohar: Anthology of Texts. 3 vols (London, 1994) Vol. 2. 628.

${ }^{46}$ Odeberg, 3 Enoch... 1.119.

${ }^{47}$ Tishby, The Wisdom of the Zohar... Vol. 2. 628: «it is the mystery of the boy who reaches old age and then reverts to his youth as at the beginning».

${ }^{48}$ Odeberg, 3 Enoch... 1.80.

${ }^{49}$ Barsov's manuscript [B], ch. V in M. И. Соколов, Материалы и заметки по старинной славянской литературе. Выпуск третий, VII: Славянская Книга Еноха Праведного / Тексты, латинский пер. и исследование. Посмертный труд автора ПрИГОТОВИЛ к иЗД. М. СПЕРАНСКИЙ // ЧОИДР 4 (1910) 85.

${ }^{50}$ Andersen, 2 Enoch... 119.

${ }^{51}$ Odeberg, 3 Enoch... 2.6-7.

52 On Merkabah stratum of the shorter recension see A. ORLov, «Merkabah Stratum» of the Short Recension of 2 Enoch (M. A. Thesis; Abilene, 1995). 
ever you see, Youth (юNoше), things standing still and moving about were brought to perfection by me. And not even to my angels have I explained my secrets... as I am making them known to you today" »..$^{53}$ As we can see in the passage the title «Youth» stresses the unique role of Enoch-Metatron among other archangels-princes, despite his young angelic age.

In spite of the abundance of the information about $\mathrm{Na}^{c}$ ar in Merkabah literature, the title itself, in many respects, remains a mysterious theological puzzle. Perhaps the most mysterious thing connected with this title is the fact that prominent scholars of Jewish mystical literature like Scholem and Odeberg do not find the important title in the narrative of 2 Enoch. One possible explanation may be that Vaillant did not pay enough attention to the variants of the reading of the term «Youth» in his edition, considering this reading as a «corruption», ${ }^{54}$ and consequently dedicating just a few sentences to this fact. According to Vaillant this «corruption» occurred because the Slavonic word GNoше, the vocative form of «Enoch», is very similar to «Youth», юNoше. ${ }^{55}$ This probably explains why those scholars who based their research on Vaillant's text also missed this vital point. Only the new collation of manuscripts for Andersen's translation again drew attention to this variant. Andersen gives a short concluding note on the term «Youth» that «It cannot be a coincidence that this title is identical with that of Enoch (= Metatron) in 3 Enoch». ${ }^{56}$

\section{The Governor of the World}

The Merkabah tradition stresses the role of Metatron as «governing power over the nations, kingdoms and rulers on earth». ${ }^{57}$ Chapter 30 of 3 Enoch pictures Metatron as the Prince of the Worldロל הע העים, the leader of seventy-two princes of the kingdom of the world, who speaks (pleads) in favor of the world before the Holy One. ${ }^{58}$ Odeberg notes that «the Prince of the World

${ }^{53}$ Barsov's manuscript [B], ch. XI in Соколов, Материалы и заметки... VII: Славянская Книга Еноха Праведного... 90-91.

${ }^{54}$ Andersen criticizes Valliant's position. He stresses that «the similarity to the vocative enoše might explain the variant as purely scribal slip. But it is surprising that it is only in address, never in description, that the term is used. The variant jenokhu is rare. There is no phonetic reason why the first vowel should change to ju; junokhu is never found». ANDERSEN, 2 Enoch... 118-119.

${ }^{55} \mathrm{Cf}$. VaILlant, Le livre des secrets d'Hénoch... 8.

${ }^{56}$ ANDERSEN, 2 Enoch... 119. Sreznevskij's dictionary equates the Slavonic word

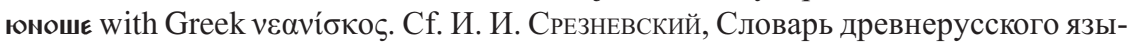
ка. 3 тт. (Москва, 1989) Т. 2. 1627-1628.

${ }^{57}$ Odeberg, 3 Enoch... 1.81.

${ }^{58}$ Ibid. 2.105. In chapter 48 of 3 Enoch the Holy One says that he «committed unto him (Metatron) 70 angels corresponding to the nations (of the world) and gave 
in 3 Enoch combines the function of the rulers of the nations: they plead each one the cause of his nation, the Prince of the World pleads the cause of all nations together, of the world in its entirety». ${ }^{59}$

Both chapter 43 of the short recension of 2 Enoch and a similar passage of the text of 2 Enoch in a Slavonic collection «The Just Balance ${ }^{60}$ reveal Enoch in his new celestial role. The texts outline Enoch's instructions to his children during his brief return to the earth in which he mentions his new role as the Governor of the earth:

And behold my children, I am the Governor ${ }^{61}$ of the earth, I wrote (them) down. And the whole year I combined and the hours of the day. ${ }^{62}$ And the hours I measured: and I wrote down every seed on earth. And I compared every measure and the just balance I measured. And I wrote (them) down, just as the Lord commanded... the doings of each person will put down, and no one will hide, because the Lord is the one who pays, and He will be the avenger on the great judgment day. ${ }^{63}$

The interesting parallel here to 3 Enoch is the fact that the role of EnochMetatron as the Governor (Prince) of the World is closely connected in both texts with the theme of Divine Judgment and with Metatron's role in that process as the Witness of the Judgment. ${ }^{64}$ As we recall in 3 Enoch these two

into his charge all the household above and below... and arranged for him all the works of Creation», Ibid. 166.

${ }^{59}$ Odeberg, 3 Enoch... 2.105.

${ }^{60}$ «The Just Balance» (Мерило Праведное) is the Slavonic collection of ethical writings in which the existence of 2 Enoch first was made public. Cf. М. Н. Тихомиров, Мерило Праведное по рукописи XIV века (Москва, 1961).

${ }^{61}$ Majority of manuscripts use Slavonic words кръмствоуемага or кормствоуемага. I. Sreznevskij in his dictionary relates these Slavonic terms to the Greek word

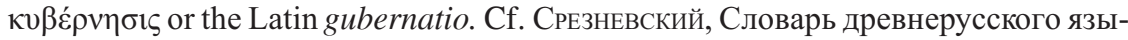
ка... Т. 1. 1410. The manuscripts of «Мерило Праведное» [MPr] use the word pravlemaya. Сf. Тихомиров, Мерило Праведное... 71. Andersen translates the term as «manager» — «I am the manager of the arrangements on earth...». ANDERSEN, 2 Enoch... 217.

${ }^{62}$ See the similar functions of Enoch in the Book of Jubilees where he «appointed times of the years according to their order, with respect to each of their months... And their weeks according to jubilees he recounted; and the days of the years he made known. And the months he set in order, and the sabbaths of the years he recounted», WinTERMUTE, Jubilees... 62-63.

${ }^{63}$ Andersen, 2 Enoch... 217-219.

${ }^{64}$ The rudimentary traces of this tradition can be found in other documents of early Enochic literature: in 1 Enoch, Aramaic Levi, and in the Book of Jubilees, where Enoch is pictured as the one «who saw what was and what will happen among the children of men in their generations until the day of judgment. He saw and knew everything and wrote his testimony and deposited the testimony upon the earth against 
themes - governing of the world and pleading for the world - remained connected together: Metatron is the Prince of the World «who pleads in the favor of the world». The narrative of 2 Enoch has a similar pattern - the title of Governor in this context means «the Mediator of the Divine Judgment ${ }^{65}$ Enoch pleads before the Lord for the world while reminding the world about the Divine Judgment.

Another interesting point about this material is the fact that the passage which is dedicated to the description of Enoch's role as «Governor of the World» is incorporated into a part of the book that is directly connected with other descriptions of the titles of Enoch. My previous observations about the celestial titles of Enoch showed that these descriptions are situated in chapters 21-38. These early chapters unfold Enoch's transformation from a human being into an angel in the highest celestial realms near the Throne of Glory.

In chapters 39-67, Enoch gives some instructions to his children during his brief visit to the earth. The text makes clear that during this visit Enoch is already an angelic being. In chapter 56 of 2 Enoch he says to his son: «Listen, my child! Since the time when the Lord anointed me with the ointment of my glory, it has been horrible for me, and food is not agreeable to me, and I have no desire for earthly food». ${ }^{66}$ This portrayal of Enoch as angelic being in this section of the book is very important, because it allows us to see traces of another tradition in the text of 2 Enoch. It is possible that in this part of the book we have some remnants of developed Metatron tradition. Chapters 3967 differ slightly from chapters $21-38$ in the ways the picture Enoch's role in the celestial realm.

First, the later chapters (43-44) give an important description of Enoch as the Governor (Prince) of the world, a role which in late Merkabah literature usually is connected with Metatron tradition.

Second, an important aspect of the passage of chapters 43-44 is the Slavonic term n( $\rho$ )ометтага (prometaya), which follows Enoch's title, «the Governor of the World». ${ }^{67}$ This Slavonic term is found solely in the text of 2 Enoch. There is no other Slavonic text where the word prometaya is documented. Phonetically close to the term «Metatron», prometaya could re-

all the children of men and their generation... And he wrote everything, and bore witness to the Watchers... And Enoch bore witness against all of them... And behold, he is there writing condemnation and judgement of the world, and all of the evils of the children of men». WinTERMUTE, Jubilees... 62.

${ }^{65}$ See $J u b .4: 24$ «...he (Enoch) was put there for a sign and so that he might relate all of the deeds of the generations until the day of judgment». WINTERMUTE, Jubilees... 63 .

${ }^{66}$ Andersen, 2 Enoch... 183.

${ }^{67}$ «And behold my children, I am the Governor of the earth, [prometaya], I wrote them down...» 
present a very early, rudimentary form of the name which later was transformed into the term «metatron». ${ }^{68}$ It is noteworthy that we cannot find the term in the early chapters connected with the descriptions of other celestial titles.

Third, at the beginning of this textual block (chapter 40) we have the following words of Enoch: «Now therefore, my children, I know everything; some from the lips of the Lord, other my eyes have seen from the beginning to the end, and from the end to the recommencement». ${ }^{69}$ This statement does not fit with previous descriptions of Enoch's initiations which were restricted by fixed temporal boundaries (angel Vereveil instructions for 30 days and 30 nights, and so on). Later, in ch. 50, Enoch says that the already «put into writing the achievements of every person, and no one can escape». ${ }^{70}$ As we recall in his deeds as the Governor of the earth he already «arranged the whole year» and he «has distinguished every seed on the earth, and every measure and every righteous scale» (43:1). This unlimited horizon of functions and deeds of Enoch is not consistent with the previous narrative of chapters 21-38. It is apparent that we have two different traditions which sometimes demonstrate the lack of linkage and reconciliation.

Finally, we must keep in mind the fact which radically differentiates 2 Enoch's story from other stories of early Enochic documents (like 1 Enoch, Jubilees or Enochic Qumran fragments). The important theological watershed of the Enochic and Metatron traditions in the book is the allegorical description of the extraction of Enoch from his «earthly clothing» and the placement of him into the «clothes of Glory». ${ }^{71}$ In 2 Enoch 22, after the archangel Michael extracted Enoch from his clothes and anointed him with the delightful oil which was «greater than the greatest light», ${ }^{72}$ Enoch becomes like «one of the glorious ones, and there was no observable difference». ${ }^{73}$

${ }^{68}$ I investigated the relationships between the words prometaya and Metatron in my article The Origin of the Name «Metatron» and the Text of 2 (Slavonic Apocalypse of) Enoch // JSP 21 (2000) 19-26.

${ }^{69}$ ANDERSEN, 2 Enoch... 165.

${ }^{70}$ Ibid. 177.

${ }^{71}$ A possible parallel to this theme could be $1 \mathrm{En}$. 71 where Enoch «was born to righteousness». The text describes the situation when Enoch went through some sort of «transformation» when his whole body was «melted» and his spirit was transformed. KNIBB, The Ethiopic Book of Enoch... Vol. 2. 166-167. However radical difference of this transformation from the similar event in 2 Enoch is the fact that transformed Enoch in 1 Enoch does not belong to the archangelic rank of «glorious ones» to which Metatron belongs. The text is silent about any sign of angelic transmutation.

72 Andersen, 2 Enoch... 139.

${ }^{73}$ Ibid. 
This symbolic event of angelic ${ }^{74}$ transmutation ${ }^{75}$ apparently represents in many ways an important turning point in which the Enochic tradition has moved into a new era of its development - the Metatron tradition. ${ }^{76}$

\section{Conclusion}

As I have already mentioned, the most impressive alignments between 2 Enoch and Merkabah tradition are dependent upon developing the themes connected with the Celestial Titles of Enoch (Metatron). They give new evidence that the Metatron tradition has deep connections with early Enochic literature. ${ }^{77}$

As we know, the process of the hidden theological transformation, when one name («Enoch») suddenly becomes transformed into another name («Metatron»), does not demonstrate the continuity of the textual tradition. On the contrary, a gap exists between the early Enochic literature (I Enoch, Jubilees, Enochic Qumran materials, 2 Enoch) and the Metatron literature (the Shicur Qomah tradition, 3 Enoch). Because of the two distinct names, it appears that the two traditions are not linked. Something seems to be missing between these two great theological streams. An important scholarly task will involve finding a «bridge» that may cross this theological gap between the prerabbinic Enoch and the rabbinic Metatron. One of the links may be found in the indissoluble continuity of the titles of this main character, which are common to both traditions. The titles, like the developed images of the heavenly roles of Enoch (Metatron), help us to see the transparent theological development which lies beneath the hidden meanings of these enigmatic names.

${ }^{74} \mathrm{~J}$. H. Charlesworth rightly observes on this episode that «it is conceivable that here Enoch - although he is not explicitly called «an angel» — has attained the rank of an angel or been transformed into angel. The possibility looms large since in 2 Enoch 21.3 Gabriel is identified as one of the Lord's glorious ones». J. H. Charlesworth, The Portrayal of the Righteous as an Angel // Ideal Figures in Ancient Judaism: Profiles and Paradigms / Ed. J. J. Collins, G. W. E. Nickelsburg (Chico, CA, 1980) (SCS, 12) 135-151 (147). Cf. also Scopello, The Apocalypse of Zostrianos... 377.

${ }^{75}$ In the Merkabah tradition we can find many parallels to this story. 3 Enoch has the similar description of the clothing of Metatron in a garment of glory. «He made me a garment of glory on which were fixed all kinds of lights and He clad me in it». ODEBERG, 3 Enoch... 2.32.

${ }^{76} \mathrm{P}$. Alexander notes that the transformation of Enoch in 2 Enoch 22 provides the closest approximation, outside Merkabah literature, to Enoch's transformation into Metatron in 3 Enoch 3-15. AlexAnder, 3 Enoch... 248.

${ }^{77}$ For a discussion of the date of 2 Enoch in the first century CE before the destruction of the Second Temple, cf. Scholem, Jewish Gnosticism... 17; and GruenwALD, Apocalyptic and Merkavah Mysticism... 50. 


\section{ABSTRACT}

The article explores the imagery of the celestial roles and titles of EnochMetatron in 2 Enoch. The analysis of the celestial roles and titles shows that the transition from the figure of patriarch Enoch to the figure of angel Metatron occurred already in 2 (Slavonic) Enoch, a Jewish work traditionally dated to the first century CE. 